\title{
Comparing the Phytoremediation Efficiency of Three Different Algae for the Nutrient Removal of Gediz River in Manisa/Turkey
}

\author{
Tuğba Şentürk*, Çisil Çamlı, Şükran Yıldız \\ Biology Department, Manisa Celal Bayar University, Manisa,Turkey, +90 2362013297 \\ tugba.sen@cbu.edu.tr \\ *Corresponding author
}

Received: 21 December 2016

Accepted: 12 June 2017

DOI: $10.18466 /$ cbayarfbe.339348

\begin{abstract}
Using bioremediation, in order to break down the pollutants of water systems, is a low cost and ecological friendly approach. Different types of algae are being used in bioremediation processes especially in contaminated waters. Algal species have the ability to use most of the pollutants as food source. Thus, they are desirable organisms for bioremediation process. Studying the bioremediation efficiency levels of different algal species for different types of contaminants is crucial for increasing the effectiveness of this method. In this study , three different algal species were used for the bioremediation process of the water samples, collected in 2015 from Gediz River. In laboratory conditions the removal efficiency of these three algae for various parameters, such as nitrate, nitrite, phosphate and ammonium, were measured. According to the results, the removal efficiency levels for (a) Chlorella sp., measured as $\mathrm{PO}_{4}{ }^{3-}>\mathrm{NO}_{3}{ }^{-}>\mathrm{NO}_{2}{ }^{-}>\mathrm{NH}_{3}{ }^{-}$, were 84.47\%, $83.41 \%, 6.22 \%, 1.79 \%$, (b) Scenedesmus sp., measured as $\mathrm{NO}_{3}{ }^{-}>\mathrm{NO}_{2}{ }^{-}>\mathrm{NH}_{3}{ }^{-}>\mathrm{PO}_{4}{ }^{3-}$, were 97.33 $\%, 92.92 \%, 72.08 \%, 56.91 \%$, and (c) Oscillatoria sp., measured as $\mathrm{NH}_{3}{ }^{-}>\mathrm{NO}_{3}{ }^{-}>\mathrm{PO}_{4}{ }^{3-}>\mathrm{NO}_{2}{ }^{-}$, were 90.08 $\%, 86.76 \%, 83.21 \%, 0.28 \%$ respectively.
\end{abstract}

Keywords - Adsorption, Chlorella, Nutrient, Oscillatoria, Phytoremediation, Scenedesmus

\section{Introduction}

Different types of pollutants and contaminants are one of the major problems of the world due to exponential increase of the population and the upsurge of the industrial activities. All these activities result in producing different types of pollution, including water pollution. Especially in the areas where industrial activities are high, as well as the high levels of domestic waste, result in increased discharged contaminants causing the water bodies to face elevated levels of pollution. Hence, the need for finding solutions to these contaminated areas becomes more and more important, especially in the challenged regions [1].

Bioremediation is defined as using living organisms to break down the pollutants of the natural environment. As compared to other methods such as mechanical or chemical cleaning, bioremediation provides less expensive and more ecologically friendly approach for removal of the contaminants. It can either be done via using domestic organisms, or through bringing organisms from another place and introducing them to the polluted area [2]. Any method that uses micro-organisms or their enzymatic activities can be considered as the process of bioremediation and microalgae are one of the most promising micro-organisms for bioremediation processes [3].

Algal species are commonly recognised as important elements for reducing pollution from the water systems $[4,5]$. Algae have the ability to use most of the pollutants as food source [6]. They consume different nutrients, which can also be pollutants for natural environments when their concentration is at high level [7]. Therefore, using algae for bioremediation offers a number of advantages. One of the most important advantages of using algae for bioremediation is that when light is provided, algae do not need oxygen due to their photosynthetic activity and thus they play an important role in fixing the carbon dioxide levels in water systems [6]. They also do not cause undesirable smells as much as bacteria [8], and more essentially, unintentional pollutant release risks can be eluded when algal species are used for remediation processes [6]. As a result of all these advantages of using algae, number of studies also have been conducted related to nutrients removal ability of algal species [1-10]. 
Choosing the suitable algal species is the most essential step for the bioremediation effectiveness. When using algae, this choice should be based on their uptake efficiency, and the growth efficiency in the given environmental conditions [5]. Thus, it is also crucial to have sufficient amount of remediation efficiency data for different algal species, and different types of pollution sources, in order to provide better results from the bioremediation processes.

Gediz River is one of the biggest rivers of western Anatolia. Around the river basin, high numbers of industrial establishments continue their activities. Mining, metal work, leather work, food and paper production are some of the focus areas of these industries. Due to this high levels of production levels, waste and pollution levels of the river is also extremely high [11]. Many of these pollutants are nutrients such as nitrate and phosphorus, which are food sources for different types of micro-organisms.

Present study aims to observe the nutrient bioremediation levels of three different algal species (Chlorella sp., Scenedesmus sp. and Oscillatoria sp.) for the water samples collected from Gediz River, since it is known as a polluted water system, and compare the results for each analysed parameter.

\section{Materials and Methods \\ 2.1 Materials}

\subsubsection{Selection and Growth of Algae}

The algal species used in this study were Chlorella sp. and Scenedesmus sp. as green algae, and Oscillatoria sp. as blue-green algae. The Chlorella sp. and Scenedesmus sp. strains were obtained from the Culture Collection of Microalgae at the University of Ege, Izmir, Turkey, and Oscillatoria sp. strains originated from Institute of CicCartuja Instituto de Bioquimica Vegetaly Fotosintesis in Spain. A standard initial inoculum of the isolated algae was inoculated to culture flasks (200 mL each) that contained $100 \mathrm{~mL}$ of sterile Bold Basal Medium [12] for two green algae and BG-11 Medium [13] for blue-green algae, and incubated at $28 \pm 1^{\circ} \mathrm{C}$ under $24 \mathrm{~h}$ light (20 E m $\mathrm{E} \mathrm{s}^{-1} \pm 20 \%$ ), with aeration (1.2 $\mathrm{L} \mathrm{min}^{-1}$ ) and magnetic stirring (100 rpm). The $\mathrm{pH}$ value was adjusted to 6-7 using $1 \mathrm{M} \mathrm{NaOH}$ and 1 $\mathrm{M}$ HCI. At the end of the incubation period (20-30 days) the cultures were filtered and washed several times by distilled water.

\subsubsection{Collection and Preparation of Water Sample}

Water samples were collected from the Gediz River, Manisa, Turkey in October, 2015 (38.661223, 27.312204). Collected water was held in the laboratory conditions for 5 days for the precipitation of the big particles. After precipitation, all the water samples were autoclaved and sterilized in order to remove all the other microorganisms that can be found in the river water.

\subsection{Methods}

\subsubsection{Analytical Methods}

The water samples from Gediz River were analyzed for $\mathrm{pH}$, phosphate, nitrate, nitrite and ammonium, before and after algal treatment using the standard techniques described by APHA, AWWA, WEF, Washington [14] and by using U.V. spectrophotometer at $700 \mathrm{~nm}, 543 \mathrm{~nm}, 543 \mathrm{~nm}$ and $640 \mathrm{~nm}$, respectively.

\subsubsection{Statistical analysis}

All experiments were conducted as triplets and all the results were provided as a mean value. Values found with spectrophotometric analysis were supported with Freundlich adsorption isotherm statistical model.

\subsubsection{Experimental Set-up and Conditions}

To compare the efficiency of algal species used, experimental set-up was defined as following:

i. To define the control group; $\mathrm{pH}$, nitrite, nitrate, ammonium and phosphate parameters of the water sample were measured before the introduction of algae (Chlorella sp., Scenedesmus sp. and Oscillatoria sp.)

ii. Each algae (Chlorella sp., Scenedesmus sp. and Oscillatoria sp.) were cultivated separately in the water samples in order study the role and efficiency of the microalgae for remediation, and $\mathrm{pH}$, nitrite, nitrate, ammonium and phosphate parameters were also measured from the water samples treated with each algae.

iii. Experiments were conducted in sets of three.

$50 \mathrm{ml}$ of algal samples were introduced to water samples with each flask containing $500 \mathrm{ml}$ of water. Dry weights for Chlorella sp. and Scenedesmus sp. were measured as $0.0114 \mathrm{mg}$ and $0.0116 \mathrm{mg}$ respectively and the wet weight of Oscillatoria sp. was measured as $2.23 \mathrm{mg}$. For Oscillatoria sp., since it was not in suspension state due to its mucilage nature, the wet weight had to be measured and the following calculations were done based on this difference. The experiment was conducted under controlled conditions. Algal cultures were incubated at $28 \pm 1^{\circ} \mathrm{C}$ temperature. 24 hour light cycle was used in order to obtain the maximum rates. Experiment was conducted for a total duration of 5 weeks. Samples were analysed every week periodically for different physico-chemical parameters as $\mathrm{pH}$, phosphate, nitrate, nitrite and ammonium.

\section{Results and Discussion}

\subsection{Nutrient removal efficiency and $\mathrm{pH}$ levels}

Preliminary analysis of the water sample revealed the $\mathrm{pH}$ level as 8.22 with alkaline nature and presence of 15.0079 $\mathrm{mg} / \mathrm{l}$ phosphate, $0.7584 \mathrm{mg} / \mathrm{l}$ nitrate, $0.8550 \mathrm{mg} / \mathrm{l}$ nitrite and 
$0.6712 \mathrm{mg} / \mathrm{l}$ ammonium. These results were taken as control values and following calculations were made based on these results. Nutrient level changes in the water samples after algal treatment were checked in an interval of one week for a period of 5 weeks.

After algal treatment of the water sample, for Chlorella sp. the average removal amounts of inorganic nutrients as phosphate $\left(\mathrm{PO}_{4}{ }^{3-}\right)$, nitrate $\left(\mathrm{NO}_{3}{ }^{-}\right)$, nitrite $\left(\mathrm{NO}_{2}^{-}\right)$and ammonium $\left(\mathrm{NH}_{3}{ }^{-}\right)$were $12.67,0.18,0.05$ and $0.012 \mathrm{mg} / \mathrm{l}$ respectively. With the same order, removal amounts were measured for Scenedesmus sp. as 8.54, 0.73, 0.79, $0.48 \mathrm{mg} / \mathrm{l}$ and for Oscillatoria sp. as 12.48, 0.65, 0.002, $0.60 \mathrm{mg} / \mathrm{l}$ (Figure $1-4)$.

The phosphate $\left(\mathrm{PO}_{4}{ }^{3-}\right)$ levels in the water sample reduced by $84.47 \%$ for Chlorella sp., $8.54 \%$ for Scenedesmus sp., and $12.48 \%$ for Oscillatoria sp. The nitrate $\left(\mathrm{NO}_{3}{ }^{-}\right)$content levels reduced by $83.41 \%$ for Chlorella sp., $97.33 \%$ for Scenedesmus sp., and $86.76 \%$ for Oscillatoria sp. The amount of nitrite $\left(\mathrm{NO}_{2}^{-}\right)$of the water sample reduced by $6.22 \%$ for Chlorella sp., 92.92\% for Scenedesmus sp., and $0.28 \%$ for Oscillatoria sp. Lastly, the ammonium $\left(\mathrm{NH}_{4}{ }^{-}\right)$levels of the water sample after the algal treatment reduced by $1.79 \%$ for Chlorella sp., 72.08\% for Scenedesmus sp. and $90.08 \%$ for Oscillatoria sp. (Figure 1-4).

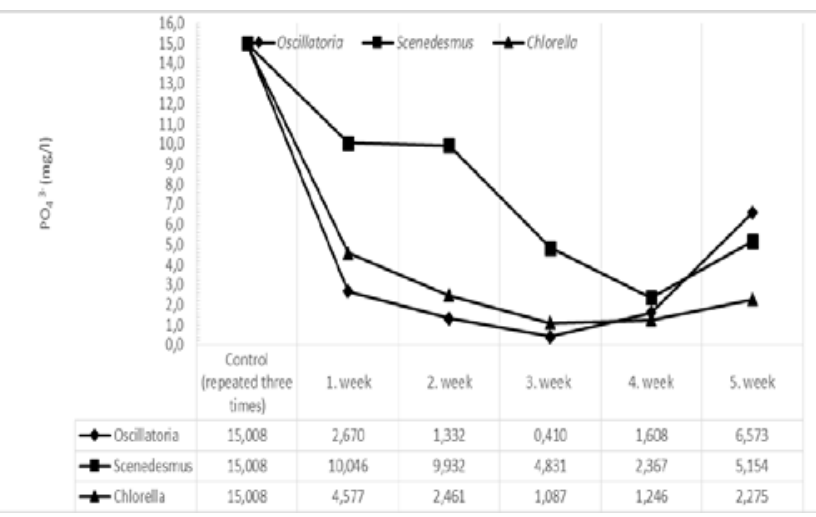

Figure 1: Phosphate $\left(\mathrm{PO}_{4}{ }^{3-}\right)$ levels of the water sample before the algal treatment and weekly changes after the treatment with Chlorella sp., Scenedesmus sp. and Oscillatoria sp.

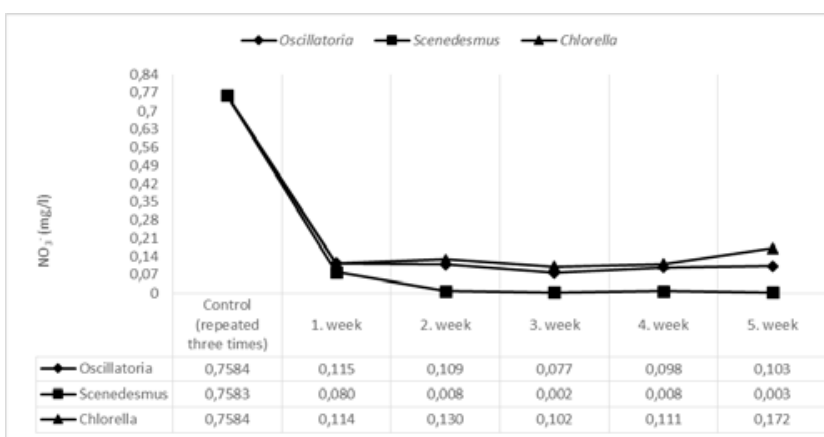

Figure 2: Nitrate $\left(\mathrm{NO}_{3}{ }^{-}\right)$levels of the water sample before the algal treatment and weekly changes after the treatment with Chlorella sp., Scenedesmus sp. and Oscillatoria sp.

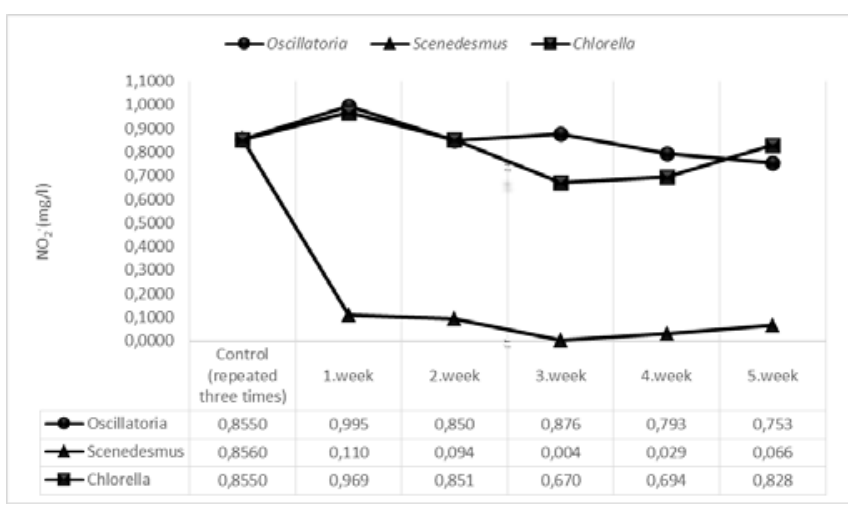

Figure 3: Nitrite $\left(\mathrm{NO}_{2}^{-}\right)$levels of the water sample before the algal treatment and weekly changes after the treatment with Chlorella sp., Scenedesmus sp. and Oscillatoria sp.

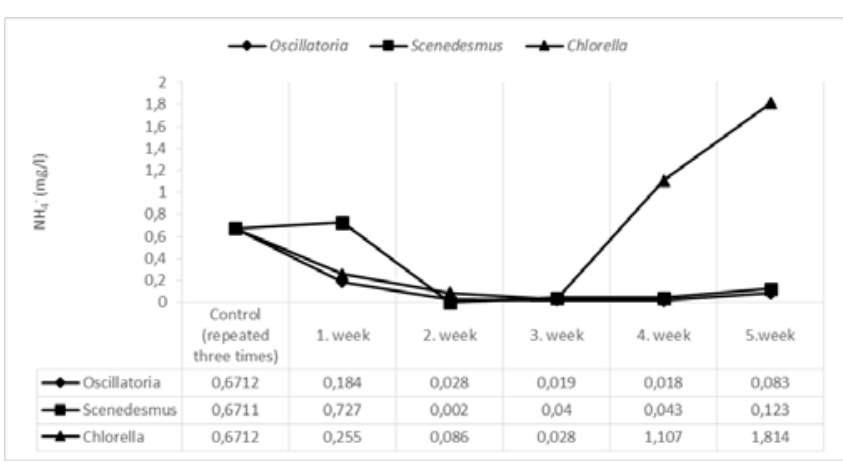

Figure 4: Ammonium $\left(\mathrm{NH}_{4}^{-}\right)$levels of the water sample before the algal treatment and weekly changes after the treatment with Chlorella sp., Scenedesmus sp. and Oscillatoria sp.

Although all the calculations were made based on the average values of the 5 weeks of treatment period, it is also important to consider the fact of desorption of nutrients throughout the time. When the weekly values are observed, after a certain time, an increase of the nutrients levels can be seen. For instance, for the phosphate treatment, after the 
4th week, it was detected that the phosphate levels increased in the water sample for all three algal treatment (Figure 1). This might indicate the fact that all three algae reached their maximum capacity of adsorption by the 4th week, and the following week desorption is observed. Similar situation was observed for the Chlorella sp. for its ammonium reduction capacity (Figure 4). Although in the measurement of the 3rd week Chlorella sp. showed a significant reduction capacity, by the 4th week, a considerable increase of the ammonium level is observed in the water sample. This also might be the indication of desorption [27-30]. Thus, it can be concluded that not only the choice of organisms but also the time of the treatment is important for the bioremediation efficiency.

Water samples used in the present study were obtained from the Gediz River in Manisa, Turkey. Gediz River is known as a highly polluted water system due to the high industrial activity [11]. Initial measurements of the water samples collected from the Gediz River obtained were $8.22 \mathrm{pH}$, $15.00 \mathrm{mg} / \mathrm{l}$ for phosphate, $0.75 \mathrm{mg} / \mathrm{l}$ for nitrate, $0.85 \mathrm{mg} / \mathrm{l}$ for nitrite, and $0.67 \mathrm{mg} / \mathrm{l}$ for ammonium. These levels already demonstrate that Gediz River has a high level of nutrient pollution, especially for phosphate, and provide a suitable sample to study the nutrient removal efficiency of algal groups [16].

Average removal efficiencies of the algal groups were measured as 84.47\%, 83.41\%, 6.22\%, $1.79 \%\left(\mathrm{PO}_{4}{ }^{3-}>\mathrm{NO}_{3}{ }^{-}>\right.$ $\mathrm{NO}_{2}{ }^{-}>\mathrm{NH}_{3}{ }^{-}$) for Chlorella sp., 97.33\%, 92.92\%, 72.08\%, $56.91 \%\left(\mathrm{NO}_{3}{ }^{-}>\mathrm{NO}_{2}{ }^{-}>\mathrm{NH}_{3}{ }^{-}>\mathrm{PO}_{4}{ }^{3-}\right)$ for Scenedesmus sp., and $90.08 \%$, 86.76\%, 83.21\%, 0.28\% $\left(\mathrm{NH}_{3}{ }^{-}>\mathrm{NO}_{3}{ }^{-}>\mathrm{PO}_{4}{ }^{3-}\right.$ $>\mathrm{NO}_{2}^{-}$) for Oscillatoria sp.

When the phosphate removal levels were compared, all three algae showed remarkable levels of efficiency. Removal percentages were measured as $84.47 \%$ for Chlorella sp., being the highest, and for Scenedesmus sp. as $56.91 \%$, being the lowest (Figure 1). These results were coherent with the study of Grantar et al. [24], who concluded Chlorella as the most efficient alga for phosphate elimination. For the nitrate removal efficiency, all three algae showed even more outstanding results. Highest percentage was measured from Scenedesmus sp. as $97.33 \%$, followed by Oscillatoria sp. as $86.76 \%$, and finally by Chlorella sp. as $83.41 \%$ (Figure 2). The result obtained for Chlorella sp. was also consistent with the study of Dominic et al. [6], which showed the nitrate reduction for Chlorella vulgaris as 84\%. Kshirsagar [1] also showed that the removal of nitrate was measured for Chlorella vulgaris as $78.08 \%$ and for Scenedesmus quadricauda as $70.32 \%$.

These results suggested that, all three algal groups used in this study were appropriate for bioremediation process of phosphate and nitrate removal. When the nitrite removal efficiencies were compared among the algal groups, although Scenedesmus sp. showed a significant removal effectiveness with 92.92\%, Chlorella sp. and Oscillatoria sp. failed as compared to Scenedesmus sp. with the removal efficiency of $6.22 \%$ and $0.28 \%$ respectively (Figure 3 ). The results from Gupta et al. [25] also indicated that Scenedesmus obliquus showed a better nitrite removal efficiency as compared to Chlorella sorokiniana. Once the algal groups were compared for the ammonium removal efficiencies, Oscillatoria sp. showed outstanding reduction level with 90.08\%, followed by Scenedesmus sp. with $72.08 \%$ reduction. However, Chlorella sp. wasn't as efficient as the other two algal groups and showed only $1.79 \%$ removal efficiency (Figure 4). González et al. [26] also showed that, although at the end both algae were similarly efficient, Scenedesmus dimorphus displayed a higher level of removal efficiency of ammonia as compared to Chlorella vulgaris in each 216 hour cycle.

The average $\mathrm{pH}$ level measured from the collected water sample was 8.22 with alkali nature. After the algal treatment it was measured on avarage for Chlorella sp., Scenedesmus sp., and Oscillatoria sp. as 9.15, 8.58 and 9.06 respectively (Figure 5).

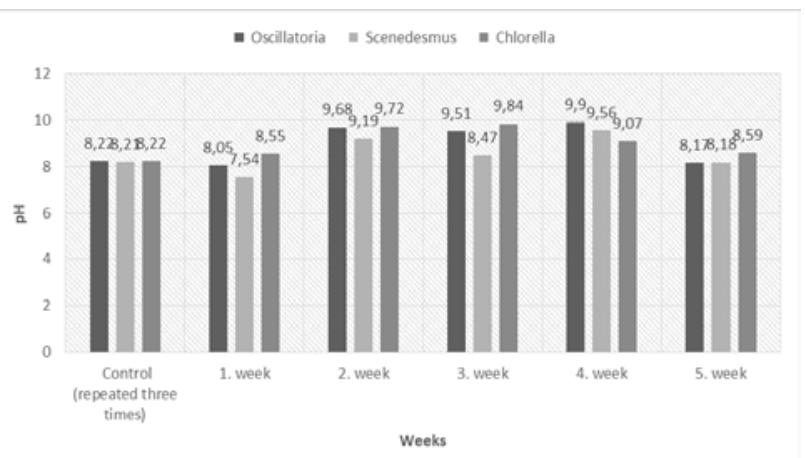

Figure 5: $\mathrm{pH}$ levels of the water sample before the algal treatment and weekly changes after the treatment with Chlorella sp., Scenedesmus sp. and Oscillatoria sp.

In this study, $\mathrm{pH}$ levels of the water samples did not show a drastic change with any of the algal treatments and stayed in the alkali nature (Figure 5). Carbon dioxide produced by respiration has an impact on lowering the $\mathrm{pH}$ levels of the water. On the other hand, as a result of photosynthesis, carbon dioxide is removed from the water and causes an increase of the $\mathrm{pH}$ levels [17]. Considering the fact that water samples in this study only included photosynthetic organisms, it was expected to observe high levels of $\mathrm{pH}$. Thus, the alkali levels of $\mathrm{pH}$ measurements of this study were consistent with the expectations.

The initial pH level was measured as 8.22. After 5 weeks of treatment with algae, the water samples stayed at alkaline. Average levels of $\mathrm{pH}$ measured for each algae were as 
Chlorella sp. > Oscillatoria sp. > Scenedesmus sp., which also can indicate the photosynthetic activity levels of these algae. When the weekly measurements were observed, 2nd, 3rd and the 4th weeks' average $\mathrm{pH}$ levels were higher than the 1st and the 5th weeks' measurements. This can be explained by the fact that in the 1st week algal groups were in the adaptation period and by the 5th week photosynthetic activity of the algal groups were decreased probably due the increased stress levels caused by remediation activity. Increased levels of $\mathrm{pH}$ were also observed in other studies. In the study of Manoharan and Subrahmanian [18] with cyanobacteria, $46.43 \%$ increase of the $\mathrm{pH}$ was reported.

The study of Kotteswari et al. [19] showed final level of $\mathrm{pH}$ as 9.82. Dominic et al. [6] reported that water sample treated with Chlorella vulgaris showed $35.79 \%$, Synechocystis salina showed 32.61\%, and Gloeocapsa gelatinosa showed $31.19 \%$ increase in the $\mathrm{pH}$ levels.

\subsection{Statistical results}

Nutrient removal capacity of the algal biomass was determined statistically by using Freundlich adsorption isotherm statistical model [15], and it was calculated based on the given formula:

$$
\mathrm{q}_{\mathrm{e}}=\mathrm{K}_{\mathrm{f}} \cdot \mathrm{C}_{\mathrm{e}}{ }^{(1 / \mathrm{n})}
$$

where $\mathrm{q}_{\mathrm{e}}$ is the mass of adsorbate adsorbed per mass of sorbent $(\mathrm{mg} / \mathrm{g}), \mathrm{C}_{\mathrm{e}}$ is the equilibrium concentration of the solute in the aqueous solution after adsorption $\left(\mathrm{mg} \mathrm{L}^{-1}\right), \mathrm{K}_{\mathrm{f}}$ is the Freundlich capacity factor and $1 / n$ is the linearity factor.

Correlation constant $\left(\mathrm{K}_{\mathrm{f}}\right)$ of studied nutrients for Chlorella sp. biomass varied as between 1.539- 29,285. These constants for Scenedesmus sp. varied between 1.617- 5.647, and for Oscillatoria sp. between 2.234-13.333. Calculated 1/n values were found for Chlorella sp. between 0.034-0.649, for Scenedesmus sp. between 0,178- 0,645 and for Oscillatoria sp. between 0.075- 0.454 (Table 1 ).

Once the statistical results were obtained, $1 / n$ values of this study varied between 0.034 - 0.649 (Table 1, Figure 6-8). According to Calace et al. [20], Kadirvelu and Namasiyayam [21], Munther [22] and Bhattacharya et al. [23] the $n$ values that varies between 1 and 10 (which means $1 / \mathrm{n}<1$ ) indicates encouraging adsorption levels. In this study, all the obtained results related to $1 / \mathrm{n}$ values, were observed between 0 and 1 . Thus, this indicates that all algal groups used provided appropriate values for adsorption levels of the given nutrients.

Freundlich adsorption isotherm statistical model results for Chlorella sp., Scenedesmus sp., and Oscillatoria sp. for each nutrient parameter are shown in the Figure 6, Figure 7 and Figure 8 respectively.
Table 1. Phosphate $\left(\mathrm{PO}_{4}{ }^{3-}\right)$, Nitrate $\left(\mathrm{NO}_{3}{ }^{-}\right)$, Nitrite $\left(\mathrm{NO}_{2}{ }^{-}\right)$ and Ammonium $\left(\mathrm{NH}_{3}{ }^{-}\right)$adsorption isotherm constants of Chlorella sp., Scenedesmus sp. and Oscillatoria sp.

\begin{tabular}{|c|c|c|c|c|c|}
\hline & $\begin{array}{l}\text { Freundlich Iso- } \\
\text { therm Con- } \\
\text { stants }\end{array}$ & $\mathrm{PO}_{4}{ }^{3-}$ & $\mathrm{NO}_{3}{ }^{-}$ & $\mathrm{NO}_{2}^{-}$ & $\mathrm{NH}_{3}{ }^{-}$ \\
\hline \multirow{3}{*}{ 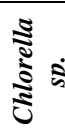 } & $1 / \mathrm{n}\left(\mathrm{L} \mathrm{g}^{-1}\right)$ & 0.649 & 0.151 & 0.034 & 0.154 \\
\hline & $\mathrm{K}_{\mathrm{f}}\left(\mathrm{L} \mathrm{g}^{-1}\right)$ & 1.539 & 6.590 & 29.285 & 6.463 \\
\hline & $\mathrm{R}^{2}$ & 0.939 & 0.956 & 0.164 & 0.952 \\
\hline \multirow{3}{*}{ 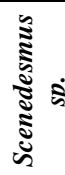 } & $1 /{\mathrm{n}\left(\mathrm{L} \mathrm{g}^{-1}\right)}$ & 0.335 & 0.625 & 0.178 & 0.645 \\
\hline & $\mathrm{K}_{\mathrm{f}}\left(\mathrm{L} \mathrm{g}^{-1}\right)$ & 2.976 & 1.674 & 5.647 & 1.552 \\
\hline & $\mathrm{R}^{2}$ & 0.861 & 0.990 & 0.447 & 0.161 \\
\hline \multirow{3}{*}{ 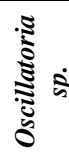 } & $1 / \mathrm{n}_{\left(\mathrm{L} \mathrm{g}^{-1}\right)}$ & 0.390 & 0.454 & 0.075 & 0.123 \\
\hline & $\mathrm{K}_{\mathrm{f}}\left(\mathrm{L} \mathrm{g}^{-1}\right)$ & 2.561 & 2.234 & 13.333 & 8.113 \\
\hline & $\mathrm{R}^{2}$ & 0.954 & 0.969 & 0.842 & 0.800 \\
\hline
\end{tabular}

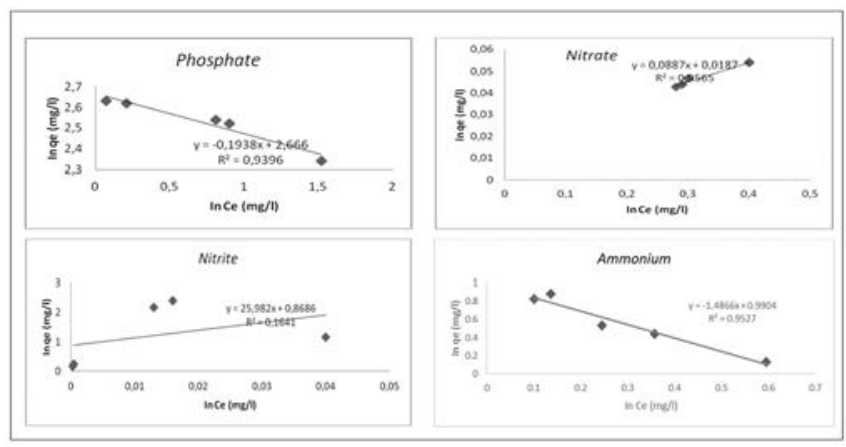

Figure 6: Freundlich adsorption isotherm results of Chlorella sp. for phosphate $\left(\mathrm{PO}_{4}{ }^{3-}\right)$, nitrate $\left(\mathrm{NO}_{3}{ }^{-}\right)$, nitrite $\left(\mathrm{NO}_{2}{ }^{-}\right.$ ) and ammonium $\left(\mathrm{NH}_{3}{ }^{-}\right)$

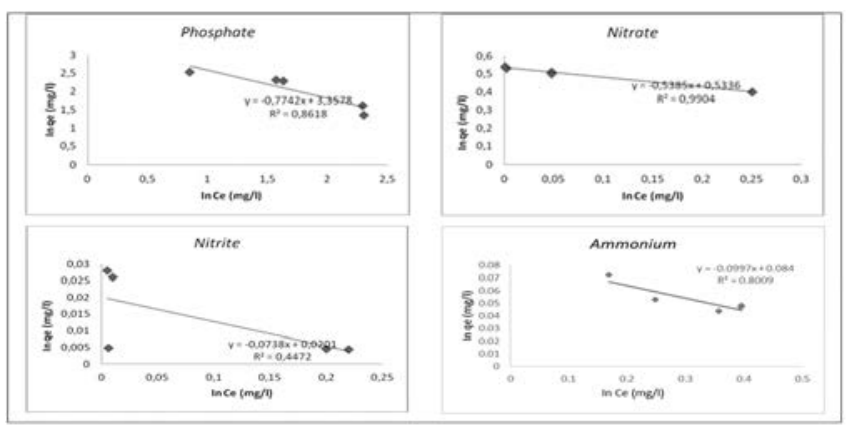

Figure 7: Freundlich adsorption isotherm results of Scenedesmus sp. for phosphate $\left(\mathrm{PO}_{4}{ }^{3-}\right)$, nitrate $\left(\mathrm{NO}_{3}{ }^{-}\right)$, nitrite $\left(\mathrm{NO}_{2}{ }^{-}\right)$and ammonium $\left(\mathrm{NH}_{3}^{-}\right)$ 


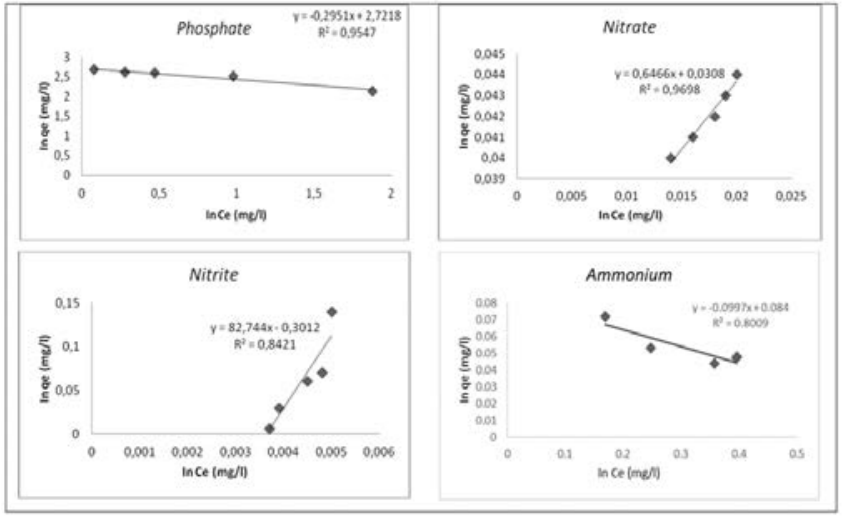

Figure 8: Freundlich adsorption isotherm results of Oscillatoria sp. for phosphate $\left(\mathrm{PO}_{4}{ }^{3-}\right)$, nitrate $\left(\mathrm{NO}_{3}{ }^{-}\right)$, nitrite $\left(\mathrm{NO}_{2}{ }^{-}\right)$and ammonium $\left(\mathrm{NH}_{3}{ }^{-}\right)$

\section{Conclusions}

Since using bioremediation is a low cost and environmental friendly approach, it is important to increase the knowledge about the remediation efficiency of different micro-organisms and different species for various pollutants in order to increase the effectiveness of this method. Thus, it is crucial to understand and compare all the results provided through the remediation studies, to be able to choose the most efficient species for the given pollution problem.

Using bioremediation offers a prospect for reducing the effects of different pollutants in the nature. Different types of algae are being used in bioremediation processes especially in contaminated waters [6]. Results of this study suggest that all three algal species tested, have the ability to remove excessive nutrients. They all can be used in polluted water environments, since they show remarkable efficiency in removal of specific nutrients, even in a highly polluted water sample like Gediz River. Obtained results also provide information for comparing which algal group has better bioremediation efficiency for the particular nutrient used in this study.

\section{References}

1. Kshirsagar, A.D. Bioremediation of wastewater by using microalgae: An experimental study, International Journal of Life Sciences Biotechnology and Pharma Research, 2013, 2(3), 339-346.

2. Vidali, M. Bioremediation: an Overview, Pure and Applied Chemistry, 2001, 73(7), 1163-1172.

3. Kensa, M.V. Bioremediation: an Overview, Journal of Industrial Pollution Control, 2001, 27(2), 161-168.

4. Han, S.Q, Zhang, Z.H, Yan, H. Present situation and developmental trend of wastewater treatment and eutrophication waters purification with alga technology, Agro Environmental Development, 2000, 63(1), 13-16.

5. Olguí, E.J. Phycoremediation: Key Issues for Cost-Effective Nutrient Removal Processes, Biotechnology Advances, 2003, 22(1), 81-91.
6. Dominic, V.J, Murali, S, Nisha, M.C. Phycoremediation Efficiency of Three Micro Algae Chlorella vulgaris, Synechocystis salina and Gloeocapsa gelatinosa, Academic review, 2009, 16(1), 138-146.

7. Muthukumaran, M, Raghavan, B.G, Subrahmanian, V.V, Sivasubrahmaniyan, V. Bioremediation of Industrial Effluent Using Micro Algae, Indian Hydrobiology, 2005, 7(1), 105-122.

8. Dwivedi, S. Bioremediation of Heavy Metal by Algae: Current and Future Perspective, Journal of Advanced Laboratory Research in Biology, 2012, 3(3), 195-199.

9. De La Noue, J, Laliberte, G, Proulx, D. Algae and Waste Water, Journal of Applied Phycology, 1992, 4(3), 247-254.

10. De Bashan, L.E, Moreno, M, Hernandez, J.P, Bashan, J. Ammonium and phosphorus removal from continuous and semi-continuous cultures by the microalgae Chlorella vulgaris coimmobilized in alginate beads with Azospirillum brasilense, Water Research, 2002, 36(12), 2941-2948.

11. Kayar, V. N, Çelik, A. Gediz Nehri Kimi Kirlilik Parametrelerinin Tayini Ve Su Kalitesinin Belirlenmesi., Ekoloji Dergisi, 2003, 12 (47), 17 22.

12. Sager, R, Granick, S. Nutritional studies with Chlamydomonas reinhardti., Annals of the New York Academy of Sciences, 1953, 56 (1), 831838.

13. Rippka, R, Desruelles, J.B, Herdman, M, Stanier, R.Y. Assignments strain history and properties of pure cultures of Cyanobacteria, Journal General Microbiology, 1979, 111 (2), 1-61.

14. APHA, AWWA, WPCF. Standard methods for the examination of water and wastewater, 20th edn. Washington, 1998, pp 1360.

15. Martinez, M.E, Sánchez, S, Jimenez, J.M, El Yousfi, F, Munoz, L. Nitrogen and phosphorus removal from urban wastewater by the microalga Scenedesmus obliquus, Bioresource technology, 2000, 73(3), 263272.

16. Zeroual, Y, Moutaouakkil, A, Dzairi, F.Z, Talbi, M, Chung, P.U, Lee, $\mathrm{K}$, Blaghen, M. Biosorption of mercury from aqueous solution by Ulva lactuca biomass, Bioresource Technology, 2003, 90(3), 349-351.

17. Malik, A. Metal bioremediation through growing cells., Environment international, 2004, 30(2), 261-278.

18. Areco, M.M, Hanela, S, Duran, J, dos Santos Afonso, M. Biosorption of $\mathrm{Cu}$ (II), Zn (II), Cd (II) and $\mathrm{Pb}$ (II) by dead biomasses of green alga Ulva lactuca and the development of a sustainable matrix for adsorption implementation, Journal of hazardous materials, 2012, 213(1), 123-132.

19. Egemen, Ö. Çevre ve Su Kirliliği; Ege Üniv. Press: İzmir, Turkey, 2006, pp 51-59.

20. Grantar, M, Gajin, S, Dalmacija, B. The possibility of phosphate elimination by the use of algae in the process of wastewater purification, Mikrobiologia, 1984, 21(1), 63-73.

21. Gupta, S.K, Ansari, F.A, Shriwastav, A, Sahoo, N.K, Rawat, I, Bux, F. Dual Role of Chlorella sorokiniana and Scenedesmus obliquus for Comprehensive Wastewater Treatment and Biomass Production for Biofuels, Journal of Cleaner Production, 2015, 115 (3), 255-264.

22. González, L.E, Cañizares, R.O, Baena, S. Efficiency of ammonia and phosphorus removal from a Colombian agroindustrial wastewater by the microalgae Chlorella vulgaris and Scenedesmus dimorphu, Bioresource 
Technology, 1997, 60(3), 259-262.

23. Aarti, N, Sumathi, P, Subrahmanian, V. Phycoremediation to improve algal water quality, Indian Hydrobiology, 2008, 11(1), 173 - 184.

24. Manoharan, C, Subrahmanian, G. Interaction between peppermill effluent and the cyanobacterium Oscillatoria pseudogerminata var. unigranulata, Pollution Research, 1992, 11(1), 73 - 84.

25. Kotteswari, M, Murugesan, S.J, Kamaleswari, K, Veeralakshmi, M. Biomanagement of diary effluent by using cyanobacterium, Indian Hydrobiology, 2007, 10(1), 109-116.

26. Freundlich, H. Uber Die Adsorption in Losungen, Zeitschrift für Physikalische Chemie,1906, 57(3), 385-470.
27. Calace, N, Muro Di, A, Nardi, E, Petronio, M.B, Pietroletti, M. Adsorption isotherms for describing heavy metal retention in paper mill sludges, Industrial and Engineering Chemistry Research, 2002, 41 (22), 54915497.

28. Kadirvelu, K, Namasivayam, C. Activated carbon from coconut coir pitch as metal adsorbent: adsorption of Cd (II) from aqueous solution, $A d$ vances in Environmental Research, 2003, 7**, 471-478.

29. Munther, I.K. Zinc and cadmium adsorption on low-grade phosphate, Separation and Purification Technology, 2004, 35(1), 61-70.

30. Bhattacharya, A.K, Mandal, S.N, Das, S.K. Adsorption of Zn (II) from aqueous solution by using different adsorbents, Chemical Engineering Journal, 2006,123(1), 43-51. 